\title{
EMPAT MODEL APROKSIMASI BINOMIAL HARGA SAHAM MODEL BLACK-SCHOLES
}

\author{
Abdul Aziz \\ Jurusan Matematika, Fakultas Sains dan Teknologi \\ Universitas Islam Negeri (UIN) Maulana Malik Ibrahim Malang \\ e-mail: abdulaziz_uinmlg@yahoo.com
}

\begin{abstract}
Abstrak
Kami akan menyajikan empat bentuk nilai parameter-parameter $u$, $d$, dan $p$ dalam model Binomial harga saham, yang dihasilkan dengan menggunakan penyamaan ekspektasi dan variansi model diskrit dengan kontinu. Metode pertama menggunakan asumsi $u . d=1$, yang mana metode ini dapat menghasilkan tiga bentuk solusi untuk parameter-parameter $u$, $d$, dan $p$ dalam model Binomial harga saham. Metode kedua menggunakan asumsi $p=0,5$. Dari kedua metode ini ternyata dapat dihasilkan empat bentuk solusi $u, d$, dan $p$ yang berbeda dan akan dibandingkan hasilnya dalam pendekatan nilai option dalam model Binomial dengan model Black-Scholes.
\end{abstract}

Kata kunci: aproksimasi, binomial, Black-Scholes, harga saham, parameter.

\section{Pendahuluan}

Call option pada sebuah saham merupakan sebuah perjanjian hak, tetapi bukan obligasi, untuk membeli saham tersebut pada suatu hari tertentu, $T$ yang akan datang, yang diistilahkan sebagai strike date atau jatuh tempo (date of expiration), dengan harga tertentu $K$, yang diistilahkan sebagai strike price atau exercise price. Sebaliknya, put option pada sebuah saham merupakan sebuah perjanjian hak untuk menjual saham pada suatu hari tertentu yang akan datang dengan harga tertentu pula (Stampfli, J., Goodman, V., 2001)

Tentu saja, pemegang option (holder) akan menggunakan atau mengabaikan hak pilihnya pada option tersebut, yang diistilahkan sebagai exercise, tergantung pada harga saham di pasar bebas pada waktu $T$ tersebut. Pemegang call option akan menggunakan haknya dengan membeli saham itu pada waktu $T$ dengan harga $K$ pada penulis option (writer), jika harga saham pada pasar bebas pada waktu $T, S_{T}$, lebih tinggi dibandingkan dengan $K$, harga saham pada option, sehingga menguntungkan bagi pemegang option. Dan, penulis option wajib untuk menjual sahamnya pada pemegang option dengan harga dan waktu sesuai perjanjian option. Sebaliknya, jika harga saham pada pasar bebas lebih rendah dibandingkan dengan strike price maka pemegang option dapat mengabaikan haknya, dan ia lebih baik membeli saham pada pasar bebas dengan harga yang lebih menguntungkan. Serupa untuk put option, pemegang option akan menjual sahamnya pada penulis option jika harga saham tersebut pada pasar bebas lebih rendah dari pada strike price. Dan, penulis option wajib membeli saham tersebut dari pemegang option. Sebaliknya, lebih baik menjual pada pasar bebas jika harga saham di pasar bebas lebih tinggi dari pada strike price.

Harga saham di pasar bebas pada waktu tertentu yang akan datang tidak dapat dipastikan oleh seseorang. Harga saham dapat mengalami perubahan turun naik setiap detiknya. Padahal, harga saham tersebut pada waktu tertentu sangat diperlukan oleh dua pihak, penulis option dan pemegang option, dalam pembuatan perjanjian option, sebagai perjanjian transaksi jual beli saham pada waktu yang akan datang. Banyak pendekatan numerik yang dilakukan oleh para ilmuan untuk memperkirakan harga saham di pasar bebas pada waktu tertentu dengan memodelkan gerakan fluktuasi harga saham, sehingga mereka dapat menentukan harga option yang mungkin menguntungkan 
bagi kedua pihak tersebut. Pemegang option akan memperoleh keuntungan, jika menggunakan hak optionnya, dari nilai option (option value) yang diperoleh dari selisih harga saham pada pasar bebas dengan harga saham pada option, yang diistilahkan dengan payoff, $\mathrm{V}$, setelah dikurangi dengan harga option (option price), yang diistilahkan dengan profit atau keuntungan (return). Sedangkan penulis option hanya memperoleh keuntungan sebesar harga atau biaya option, baik jika pemegang option menggunakan atau mengabaikannya. Jadi keuntungan atau kerugian yang diperoleh oleh pemegang call option pada waktu $T$ (Hull, John C., 2003):

$$
\text { Profit }=\text { payoff }- \text { biaya option }=V_{C}-C=\max \left(K-S_{T}, 0\right)-C
$$

Sebaliknya, bagi pemegang put option akan mendapatkan keuntungan atau kerugian:

$$
\text { Profit }=\text { payoff }- \text { biaya option }=V_{P}-C=\max \left(S_{T^{-}} K, 0\right)-P
$$

Artinya, jika profit bernilai positif maka pemegang option mendapatkan keutungan, dan sebaliknya jika negatif merupakan kerugian yang maksimal sebesar biaya option.

\section{Model Binomial Harga Saham}

Harga saham pada pasar bebas kenyataannya akan selalu berubah naik atau turun dengan perubahan waktu. Kemungkinan dua arah perubahan inilah yang digunakan sebagai dasar model binomial. Misalkan harga saham pada saat $t=0$, saat pembuatan option, adalah $S_{0}$ dan pada saat $t=T$ akan naik dengan peluang $p$ menjadi $S_{u}$ atau akan turun dengan peluang 1-p menjadi $\mathrm{S}_{\mathrm{d}}$, Sehingga nilai option pada saat $t=0$, saat pembuatan option, adalah $V_{0}$ dan pada saat $t=T$ akan naik menjadi $U$ atau akan turun menjadi $D$.
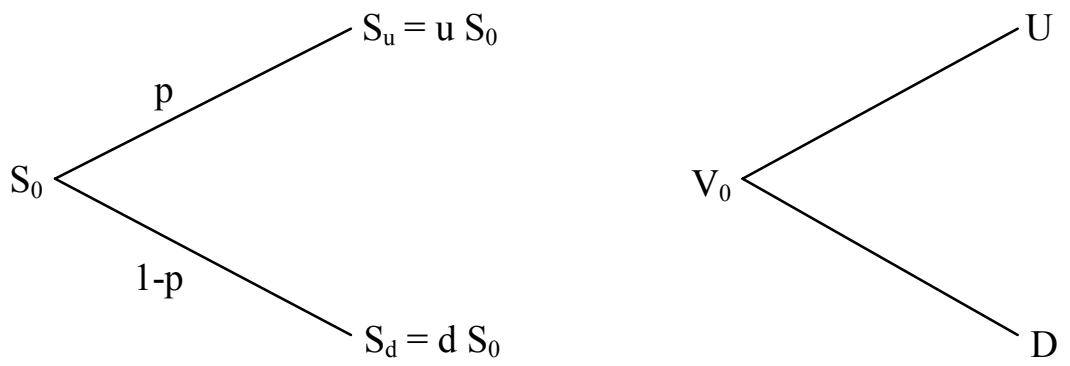

GAMBAR 1. Grafik perubahan harga saham dan harga option

Permodelan matematika diharapkan dapat membantu kita untuk memahami keadaan sekarang dan prediksinya pada waktu yang akan datang. Oleh karena itu, agar model binomial ini dapat berhasil dengan lebih baik maka harus sesuai dengan keadaan dunia nyata. Masalah yang dihadapi sekarang adalah bagaimana kita memilih $p, u$, dan $d$ sedemikian hingga model binomial ini mendekati pada keadaan dunia nyata.

Kita mulai dengan diskritisasi, yaitu menjadikan waktu kontinu $t$ menjadi diskrit dengan menggantikan $t$ oleh waktu yang sama lamanya katakanlah $t_{i}$. Misalkan kita gunakan notasi berikut:

$$
\begin{aligned}
& M: \text { banyaknya selang waktu, } \Delta t:=\frac{T}{M} \\
& t_{i}: i . \Delta t, \quad i=0,1, \ldots, M \\
& S_{i}: S\left(t_{i}\right)
\end{aligned}
$$

Selanjutnya bidang $(S, t)$ diwakili oleh garis-garis lurus paralel dengan jarak $\Delta t$. Dan kita ganti nilai-nilai kontinu $S_{i}$ sepanjang paralel $t=t_{i}$ dengan nilai-nilai diskrit $S_{\mathrm{ji}}$, untuk semua $i$ dan $j$ yang sesuai. Untuk lebih memahami lihat gambar 2. Gambar ini 
menunjukkan sebuah hubungan grid, katakanlah perubahan dari $t$ ke $t+\Delta t$, atau dari $t_{i}$ ke $t_{i+1}$.

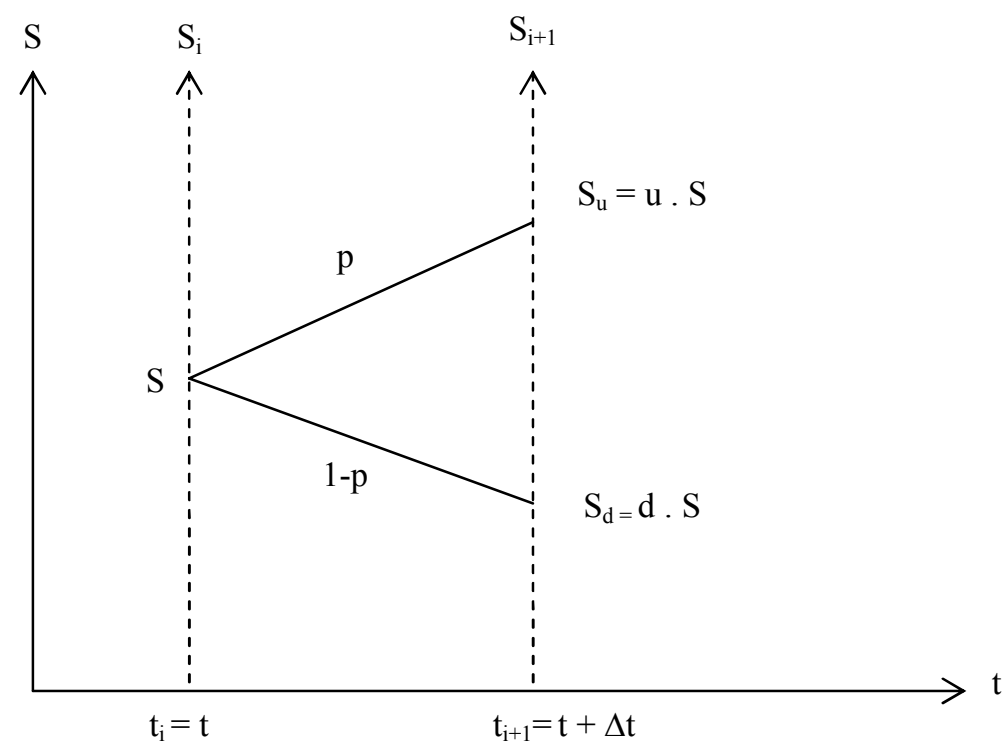

GAMBAR 2. Prinsip metode binomial

Sehingga asumsi-asumsi yang digunakan dalam permodelan ini adalah (Figlewski, Stephen, 1990):

(A1) Harga $S$, sebagai harga awal, selama setiap periode waktu $\Delta t$ hanya dapat berubah dalam dua kemungkinan yaitu naik menjadi $S_{u}$ atau turun menjadi $S_{d}$ dengan $0<d$ $<u$. Di sini $u$ dan $d$ masing-masing merupakan faktor perubahan naik dan turun yang konstan untuk setiap $\Delta t$.

(A2) Peluang perubahan naik adalah $p, \mathrm{P}($ naik $)=p$. Sehingga $\mathrm{P}($ turun $)=1-p$.

(A3) Ekspektasi harga saham secara acak kontinu, dengan suku bunga bebas resiko $r$, dari $S_{i}$ pada waktu $t_{i}$ menjadi $S_{i+1}$ pada waktu $t_{i+1}$ adalah:

$$
E\left(S_{i+1}\right)=S_{i} \cdot e^{r \Delta t} \text {. }
$$

Asumsi selanjutnya adalah tidak ada pembayaran dividen selama periode waktu tersebut. Jika ada pembayaran dividen, q, maka persamaan (2.1) menjadi $E\left(S_{i+1}\right)=S_{i} \cdot e^{(r-q) \Delta t}$ Dengan model binomial kita bisa membangun skema (tree) untuk fluktuasi harga saham secara diskrit.

Dari gambar 3, kita misalkan harga saham pada saat $t=t_{0}$ adalah $S_{0}=S_{00}=S$, dan harga saham pada saat $t=t_{1}$ adalah $S_{01}=S d$ dan $S_{11}=S u$. Sehingga secara umum harga saham pada saat $t=t_{i}$ terdapat $i+1$ kemungkinan dengan rumus umum

$$
S_{j i}=S_{0} u^{j} d^{i-j}, i=0,1, \ldots, M \operatorname{dan} j=0,1, \ldots i \text {. }
$$

Sehingga diperoleh nilai-nilai option, untuk European call option

dan untuk European put option

$$
V_{j M}=\max \left(S_{j M}-K, 0\right) \text {, }
$$

$$
V_{j M}=\max \left(K-S_{j M}, 0\right) .
$$

Pada American Option, kita bisa meng-exercise sebelum jatuh tempo, $t \leq T$, sehingga perlu juga untuk menghitung nilai-nilai option untuk $t_{i}$ dimana $i=M-1$, $M-2, \ldots, 0$, karena ada kemungkinan nilai-nilai option di waktu-waktu tersebut lebih baik dari pada pada waktu jatuh temponya. (Ross, Sheldon M., 1999) 
Persamaan (1) adalah tidak rekursif, artinya perhitungan yang memerlukan waktu relatif lama, sehingga perlu adanya bentuk rekursif yang diperoleh sebagai berikut, dengan bantuan persamaan

$$
E\left(S_{i+1}\right)=S_{i} e^{r \Delta t}
$$

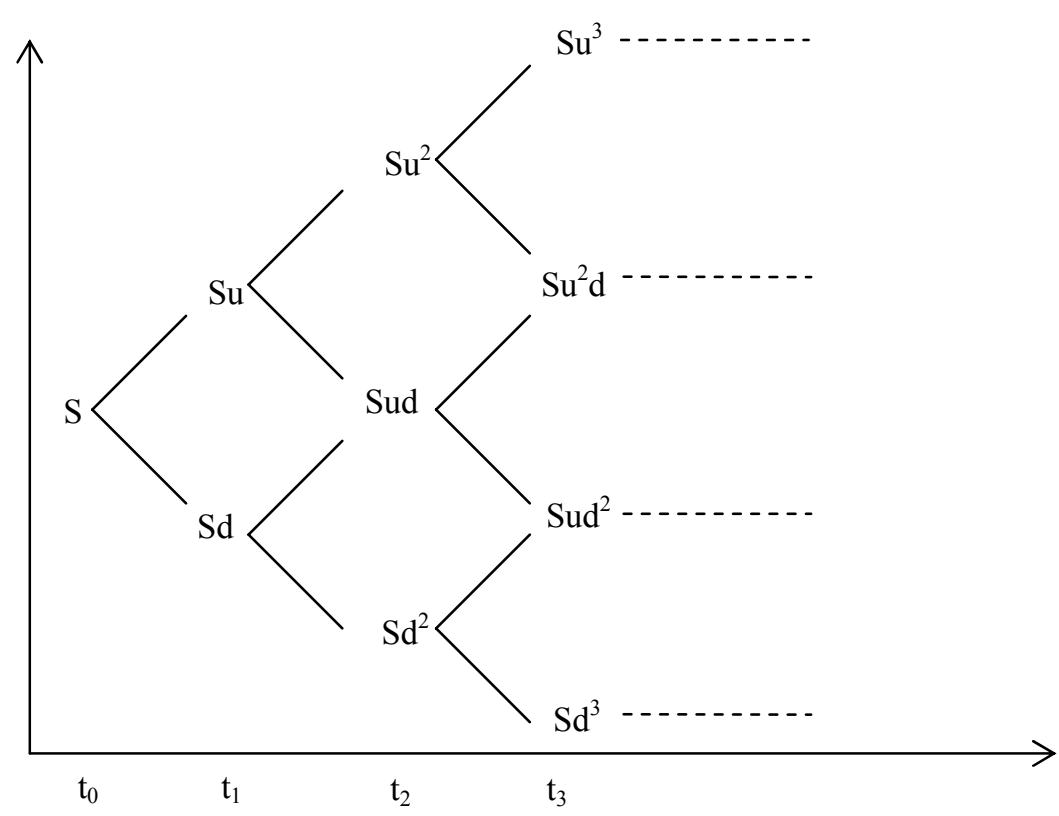

GAMBAR 3. Skema fluktuasi harga saham secara binomial

Sedangkan

$$
S_{j i} e^{r \Delta t}=E\left(S_{j, i+1}\right)=p S_{j i} u+(1-p) S_{j i} d=p S_{j+1, i+1}+(1-p) S_{j, i+1} .
$$

Sehingga bentuk rekursif untuk nilai option, $V$,

$$
V_{j i}=e^{-r \Delta t} E\left(V_{j, i+1}\right)=e^{-r \Delta t}\left(V_{j i} e^{r \Delta t}\right)=e^{-r \Delta t}\left(p V_{j+1, i+1}+(1-p) V_{j, i+1}\right) \text {. }
$$

Jadi, nilai-nilai option untuk European Call Option

$$
\begin{gathered}
V_{j M}=\max \left(S_{j M}-K, 0\right), \text { dan } \\
V_{j i}=e^{-r \Delta t}\left(p V_{j+1, i+1}+(1-p) V_{j, i+1}\right)
\end{gathered}
$$

dan untuk European Put Option

$$
\begin{gathered}
V_{j M}=\max \left(K-S_{j M}, 0\right), \text { dan } \\
V_{j i}=e^{-r \Delta t}\left(p V_{j+1, i+1}+(1-p) V_{j, i+1}\right),
\end{gathered}
$$

sedangkan untuk American Call Option

$$
\begin{gathered}
V_{j M}=\max \left(S_{j M}-K, 0\right), \text { dan } \\
V_{j i}=\max \left\{\max \left(S_{j i}-K, 0\right), e^{-r \Delta t}\left(p V_{j+1, i+1}+(1-p) V_{j, i+1}\right)\right\}
\end{gathered}
$$

dan untuk American Put Option

$$
\begin{gathered}
V_{j M}=\max \left(K-S_{j M}, 0\right), \text { dan } \\
V_{j i}=\max \left\{\max \left(K-S_{j i}, 0\right), e^{-r \Delta t}\left(p V_{j+1, i+1}+(1-p) V_{j, i+1}\right)\right\}
\end{gathered}
$$

untuk $i=0,1, \ldots, M$ dan $j=0,1, \ldots, i$.

\section{Metode I, dengan asumsi u.d $=1$}

Untuk menentukan tiga parameter yang belum diketahui, $u, d$, dan $p$, diperlukan tiga persamaan, yaitu (Stampfli, J., Goodman, V., 2001): 
(P.1) Menyamakan ekspektasi harga saham model diskrit dengan model kontinu.

(P.2) Menyamakan variansi model diskrit dengan model kontinu.

(P.3) Menyamakan $u . d=1$.

Konsekuensi dari asumsi (A1) dan (A2) untuk model diskrit ini adalah

$$
E\left(S_{i+1}\right)=p S_{i} u+(1-p) S_{i} d=S_{i}(p u+(1-p) d) .
$$

Di sini $S_{\mathrm{i}}$ adalah sebuah nilai sebarang untuk $t_{\mathrm{i}}$, yang berubah secara acak menjadi $\mathrm{S}_{\mathrm{i}+1}$, sehingga sesuai kedua asumsi tersebut persamaan (2) dan (3) memberikan

$$
e^{r \Delta t}=p u+(1-p) d \text {. }
$$

Ini merupakan persamaan pertama yang diperlukan untuk menentukan $u, d, p$.

Selanjutnya perhatikan bahwa dengan menyelesaikan persamaan (4) untuk $p$ akan diperoleh:

$$
\begin{aligned}
e^{r \Delta t}=p u+(1-p) d & =p u+d-p d=p(u-d)+d \\
p & =\frac{e^{r \Delta t}-d}{u-d} .
\end{aligned}
$$

Karena p merupakan peluang yang harus memenuhi $0 \leq p \leq 1$ maka haruslah $e^{r \Delta t}-d \leq u-d$ atau $e^{r \Delta t} \leq u$ dan $u-d>0$ atau $d \leq u$, sehingga diperoleh

$$
d \leq e^{r \Delta t} \leq u \text {. }
$$

Pertidaksamaan-pertidaksamaan ini berhubungan dengan gerakan naik dan turunnya harga aset terhadap suku bunga bebas resiko r. Pertidaksamaan terakhir ini bukanlah merupakan asumsi baru tetapi merupakan prinsip no-arbitrage bahwa $0<d<u$.

Selanjutnya kita menghitung variansi. Dari model kontinu kita terapkan hubungan

$$
E\left(S_{i+1}^{2}\right)=S_{i}^{2} e^{\left(2 r+\sigma^{2}\right) \Delta t}
$$

Persamaan (2) dan (6) menghasilkan variansi

$$
\operatorname{Var}\left(S_{i+1}\right)=E\left(S_{i+1}^{2}\right)-\left(E\left(S_{i+1}\right)\right)^{2}=S_{i}^{2} e^{\left(2 r+\sigma^{2}\right) \Delta t}-S_{i}^{2} e^{2 r \Delta t}=S_{i}^{2} e^{2 r \Delta t}\left(e^{\sigma^{2} \Delta t}-1\right) .
$$

Di sisi lain, dengan menggunakan persamaan (3) dan (4), varian untuk model diskrit memenuhi

$$
\begin{aligned}
\operatorname{Var}\left(S_{i+1}\right) & =E\left(S_{i+1}^{2}\right)-\left(E\left(S_{i+1}\right)\right)^{2}=p\left(S_{i} u\right)^{2}+(1-p)\left(S_{i} d\right)^{2}-\left(S_{i}(p u+(1-p) d)\right)^{2} \\
& =S_{i}^{2}\left(p u^{2}+(1-p) d^{2}\right)-\left(S_{i} e^{r \Delta t}\right)^{2}=S_{i}^{2}\left(p u^{2}+(1-p) d^{2}-e^{2 r \Delta t}\right)
\end{aligned}
$$

Sehingga dengan menyamakan hasil kedua variansi tersebut, persamaan (6) dan (7), menghasilkan

$$
\begin{gathered}
S_{i}^{2} e^{2 r \Delta t}\left(e^{\sigma^{2} \Delta t}-1\right)=S_{i}^{2}\left(p u^{2}+(1-p) d^{2}-e^{2 r \Delta t}\right) \\
e^{2 r \Delta t}\left(e^{\sigma^{2} \Delta t}-1\right)=p u^{2}+(1-p) d^{2}-e^{2 r \Delta t} \\
e^{\left(2 r+\sigma^{2}\right) \Delta t}=p u^{2}+(1-p) d^{2} \\
e^{\left(2 r+\sigma^{2}\right) \Delta t}=p\left(u^{2}-d^{2}\right)+d^{2} \\
p=\frac{e^{\left(2 r+\sigma^{2}\right) \Delta t}-d^{2}}{u^{2}-d^{2}}
\end{gathered}
$$

Selanjutnya, dengan menyamakan persamaan (5) dan (8) serta misalkan kita memilih menyamakan $u . d=1$ akan dihasilkan

$$
\begin{gathered}
\frac{e^{r \Delta t}-d}{u-d}=\frac{e^{\left(2 r+\sigma^{2}\right) \Delta t}-d^{2}}{u^{2}-d^{2}} \\
\frac{e^{r \Delta t}-d}{u-d}=\frac{e^{\left(2 r+\sigma^{2}\right) \Delta t}-d^{2}}{(u-d)(u+d)} \\
(u+d)\left(e^{r \Delta t}-d\right)=e^{\left(2 r+\sigma^{2}\right) \Delta t}-d^{2} \\
u e^{r \Delta t}+d e^{r \Delta t}-u d-d^{2}=e^{\left(2 r+\sigma^{2}\right) \Delta t}-d^{2}
\end{gathered}
$$




$$
\begin{gathered}
(u+d) e^{r \Delta t}-1-d^{2}=e^{\left(2 r+\sigma^{2}\right) \Delta t}-d^{2} \\
(u+d) e^{r \Delta t}-1=e^{\left(2 r+\sigma^{2}\right) \Delta t} \\
(u+d) e^{r \Delta t}-1=e^{\left(r+\sigma^{2}\right) \Delta t} e^{r \Delta t} \\
\left(u+d-e^{-r \Delta t}\right) e^{r \Delta t}=e^{\left(r+\sigma^{2}\right) \Delta t} e^{r \Delta t} \\
u+d-e^{-r \Delta t}=e^{\left(r+\sigma^{2}\right) \Delta t} \\
u+\frac{1}{u}-e^{-r \Delta t}=e^{\left(r+\sigma^{2}\right) \Delta t} \\
u^{2}+1-u e^{-r \Delta t}=u e^{\left(r+\sigma^{2}\right) \Delta t} \\
u^{2}+1-u e^{-r \Delta t}-u e^{\left(r+\sigma^{2}\right) \Delta t}=0 \\
u^{2}-u\left(e^{-r \Delta t}+e^{\left(r+\sigma^{2}\right) \Delta t}\right)+1=0 \\
u^{2}-u\left(e^{-r \Delta t}+e^{\left(r+\sigma^{2}\right) \Delta t}\right)+1=0
\end{gathered}
$$

Dengan memisalkan $\beta=1 / 2\left(e^{-r \Delta t}+e^{\left(r+\sigma^{2}\right) \Delta t}\right)$ persamaan (9) menjadi persamaan kuadrat yang lebih sederhana yaitu

$$
u^{2}-2 \beta u+1=0
$$

dengan akar-akar $u=\beta \pm \sqrt{\beta^{2}-1}$ dimana $\beta^{2}-1>0$.

Karena $d<u$ maka kita pilih $u=\beta+\sqrt{\beta^{2}-1}$ sehingga diperoleh nilai untuk $u, d$ dan $p$ yaitu

$$
u=\beta+\sqrt{\beta^{2}-1}, d=1 / u, p=\frac{e^{r \Delta t}-d}{u-d} \operatorname{dengan} \beta=1 / 2\left(e^{-r \Delta t}+e^{\left(r+\sigma^{2}\right) \Delta t}\right)
$$

Selanjutnya, dengan aproksimasi bilangan eksponensial $e^{x} \approx 1+x$ akan diperoleh nilai untuk $\beta$

$$
\beta=1 / 2\left(1-r \Delta t+1+\left(r+\sigma^{2}\right) \Delta t\right)=1 / 2\left(2+\sigma^{2} \Delta t\right)=1+1 / 2 \sigma^{2} \Delta t
$$

sehingga untuk nilai $u$

$$
\begin{aligned}
u & =\left(1+1 / 2 \sigma^{2} \Delta t\right)+\sqrt{\left(1+1 / 2 \sigma^{2} \Delta t\right)^{2}-1}=1+1 / 2 \sigma^{2} \Delta t+\sqrt{1+\sigma^{2} \Delta t+1 / 4 \sigma^{4} \Delta t-1} \\
& =1+1 / 2 \sigma^{2} \Delta t+\sqrt{\sigma^{2} \Delta t+1 / 4 \sigma^{4} \Delta t} \approx 1+1 / 2 \sigma^{2} \Delta t+\sqrt{\sigma^{2} \Delta t}=1+1 / 2 \sigma^{2} \Delta t+\sigma \sqrt{\Delta t} \\
& \approx 1+\sigma \sqrt{\Delta t} \approx e^{\sigma \sqrt{\Delta t}}
\end{aligned}
$$

Sehingga kita memperoleh nilai $u, d$ dan $p$ sebagai

$$
u=e^{\sigma \sqrt{\Delta t}}, d=e^{-\sigma \sqrt{\Delta t}} \text {, dan. } p=\frac{e^{r \Delta t}-d}{u-d} .
$$

Nilai-nilai dari parameter-parameter terakhir ini telah diperkenalkan oleh Cox, Ross, dan Rubinstein. ${ }^{7}$

Atau jika diinginkan juga untuk nilai $p$

$$
\begin{aligned}
p & =\frac{e^{r \Delta t}-d}{u-d}=\frac{e^{r \Delta t}-e^{-\sigma \sqrt{\Delta t}}}{e^{\sigma \sqrt{\Delta t}}-e^{-\sigma \sqrt{\Delta t}}}=\frac{e^{r \Delta t}-e^{-\sigma \sqrt{\Delta t}}}{e^{\sigma \sqrt{\Delta t}}-e^{-\sigma \sqrt{\Delta t}}} \frac{e^{\sigma \sqrt{\Delta t}}}{e^{\sigma \sqrt{\Delta t}}}=\frac{e^{r \Delta t+\sigma \sqrt{\Delta t}}-1}{e^{2 \sigma \sqrt{\Delta t}}-1} \\
& \approx \frac{1+r \Delta t+\sigma \sqrt{\Delta t}-1}{1+2 \sigma \sqrt{\Delta t}-1}=\frac{r \Delta t+\sigma \sqrt{\Delta t}}{2 \sigma \sqrt{\Delta t}}=\frac{(r / \sigma \sqrt{\Delta t}+1) \sigma \sqrt{\Delta t}}{2 \sigma \sqrt{\Delta t}}=\frac{1}{2}\left(\frac{r}{\sigma} \sqrt{\Delta t}+1\right) .
\end{aligned}
$$

Sehingga kita memperoleh nilai $u, d$ dan $p$ yang lain sebagai

$$
u=e^{\sigma \sqrt{\Delta t}}, d=e^{-\sigma \sqrt{\Delta t}} \text {, dan } p=1 / 2(r / \sigma \sqrt{\Delta t}+1) .
$$




\section{Metode II, dengan asumsi $\mathbf{p}=\mathbf{0 . 5}$}

Sekarang, kita coba membandingkan metode di atas dengan memilih $p=0.5$ pada (P.3) untuk menghitung ulang dalam menentukan nilai $u$ dan $d$. Dan tetap dengan menyamakan ekspektasi dan rata-rata pada model kontinu dan diskritnya sebagaimana metode sebelumnya.

Dengan mensubstitusikan nilai $p$ dada persamaan (5) diperoleh

$$
e^{r \Delta t}=p u+(1-p) d=0.5 u+0.5 d=0.5(u+d)
$$

sehingga

dan pada persamaan (8) diperoleh

$$
u+d=2 e^{r \Delta t}
$$

$$
p=\frac{e^{\left(2 r+\sigma^{2}\right) \Delta t}-d^{2}}{u^{2}-d^{2}}=\frac{1}{2}
$$

sehingga

$$
u^{2}+d^{2}=2 e^{\left(2 r+\sigma^{2}\right) \Delta t} \text {. }
$$

Misalkan $u=b+c$ dan $d=b-c$ maka diperoleh

$$
u+d=b+c+b-c=2 b=2 e^{r \Delta t} \text { atau } b=e^{r \Delta t}
$$

dan

atau

sehingga

$$
u^{2}+d^{2}=b^{2}+2 b c+c^{2}+b^{2}-2 b c+c^{2}=2 b^{2}+2 c^{2}=2 e^{\left(2 r+\sigma^{2}\right) \Delta t}
$$

atau

$$
e^{\left(2 r+\sigma^{2}\right) \Delta t}=b^{2}+c^{2}=e^{2 r \Delta t}+c^{2}
$$

$$
c^{2}=e^{\left(2 r+\sigma^{2}\right) \Delta t}-e^{2 r \Delta t}=e^{2 r \Delta t}\left(e^{\sigma^{2} \Delta t}-1\right)
$$

Sehingga diperoleh

$$
c=e^{r \Delta t} \sqrt{e^{\sigma^{2} \Delta t}-1}
$$

$$
u=e^{r \Delta t}+e^{r \Delta t} \sqrt{e^{\sigma^{2} \Delta t}-1}=e^{r \Delta t}\left(1+\sqrt{e^{\sigma^{2} \Delta t}-1}\right)
$$

dan

$$
d=e^{r \Delta t}-e^{r \Delta t} \sqrt{e^{\sigma^{2} \Delta t}-1}=e^{r \Delta t}\left(1-\sqrt{e^{\sigma^{2} \Delta t}-1}\right)
$$

Jadi, dengan metode ini diperoleh

$$
u=e^{r \Delta t}\left(1+\sqrt{e^{\sigma^{2} \Delta t}-1}\right), d=e^{r \Delta t}\left(1-\sqrt{e^{\sigma^{2} \Delta t}-1}\right), p=\frac{1}{2} .
$$

\section{Perbandingan Hasil Numerik}

Dari kedua metode di atas ternyata dapat diperoleh empat bentuk solusi nilai-nilai untuk parameter-parameter $u, d$, dan $p$ dalam model Binomial, yaitu

$$
\begin{gathered}
u=\beta+\sqrt{\beta^{2}-1}, d=1 / u, p=\frac{e^{r \Delta t}-d}{u-d} \text { dengan } \beta=1 / 2\left(e^{-r \Delta t}+e^{\left(r+\sigma^{2}\right) \Delta t}\right) \\
u=e^{\sigma \sqrt{\Delta t}}, d=e^{-\sigma \sqrt{\Delta t}} \text {, dan. } p=\frac{e^{r \Delta t}-d}{u-d} . \\
u=e^{\sigma \sqrt{\Delta t}}, d=e^{-\sigma \sqrt{\Delta t}}, \text { dan } p=1 / 2(r / \sigma \sqrt{\Delta t}+1) . \\
u=e^{r \Delta t}\left(1+\sqrt{e^{\sigma^{2} \Delta t}-1}\right), d=e^{r \Delta t}\left(1-\sqrt{e^{\sigma^{2} \Delta t}-1}\right), p=\frac{1}{2} .
\end{gathered}
$$


Berikut ini adalah tabel dan grafik hasil komputasi numerik untuk menghitung nilai European Option dengan keempat model binomial solusi aproksimasi parameterparameter di atas yang juga diperbandingkan dengan nilai option dengan model BlackScholes. Pada contoh di sini menggunakan data-data: $S=5, K=10, r=0.06 . \sigma=0.3$, $T=1$.

TABEL 1. Hasil Numerik Nilai European Put Option

\begin{tabular}{cccccccc}
\hline M & 8 & 16 & 32 & 64 & 128 & 256 & 512 \\
\hline Model 1 & 4.4251 & 4.4292 & 4.4299 & 4.4299 & 4.4300 & 4.4304 & 4.4304 \\
Model 2 & 4.4248 & 4.4289 & 4.4297 & 4.4298 & 4.4300 & 4.4304 & 4.4304 \\
Model 3 & 4.2010 & 4.2057 & 4.2065 & 4.2065 & 4.2067 & 4.2071 & 4.2071 \\
Model 4 & 4.4247 & 4.4293 & 4.4298 & 4.4296 & 4.4302 & 4.4303 & 4.4304 \\
BS & 4.4305 & 4.4305 & 4.4305 & 4.4305 & 4.4305 & 4.4305 & 4.4305 \\
\hline
\end{tabular}

TABEL 2. Hasil Numerik Nilai European Call Option

\begin{tabular}{clcccccc}
\hline Periode & \multicolumn{1}{c}{8} & 16 & 32 & 64 & 128 & 256 & 512 \\
\hline Model 1 & 0.0074 & 0.0116 & 0.0122 & 0.0123 & 0.0124 & 0.0127 & 0.0127 \\
Model 2 & 0.0071 & 0.0112 & 0.0120 & 0.0122 & 0.0124 & 0.0127 & 0.0127 \\
Model 3 & 0.107 & 0.0168 & 0.0183 & 0.0187 & 0.0190 & 0.0195 & 0.0195 \\
Model 4 & 0.0071 & 0.0117 & 0.0121 & 0.0120 & 0.0126 & 0.0126 & 0.0128 \\
BS & 0.0128 & 0.0128 & 0.0128 & 0.0128 & 0.0128 & 0.0128 & 0.0128 \\
\hline
\end{tabular}

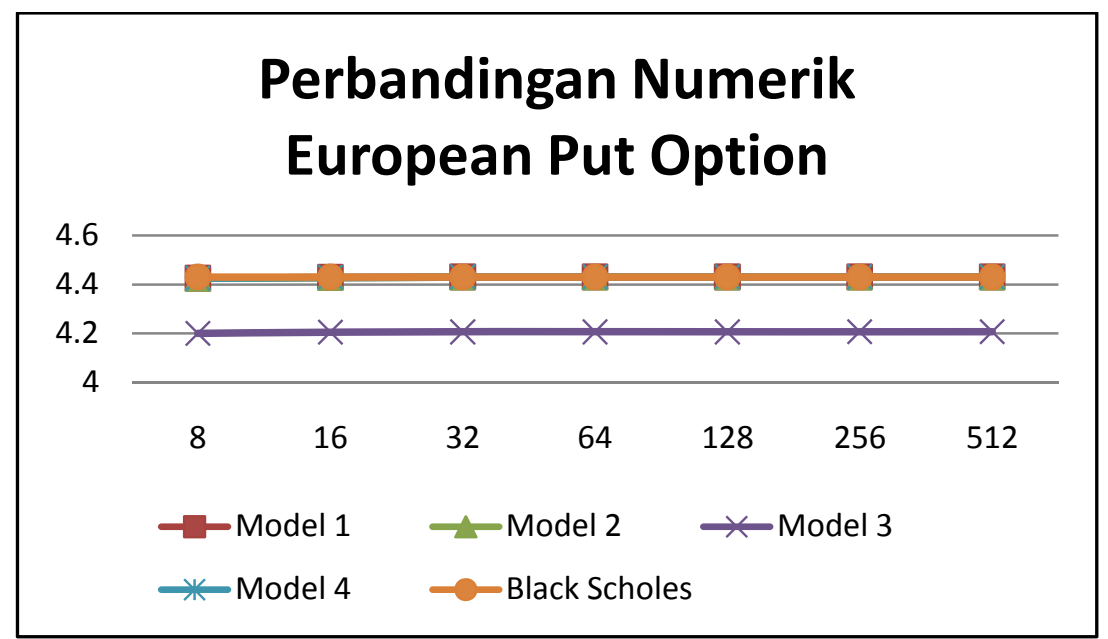

GAMBAR 4. Perbandingan Numerik European Put Option Model 1, 2,3 dan 4

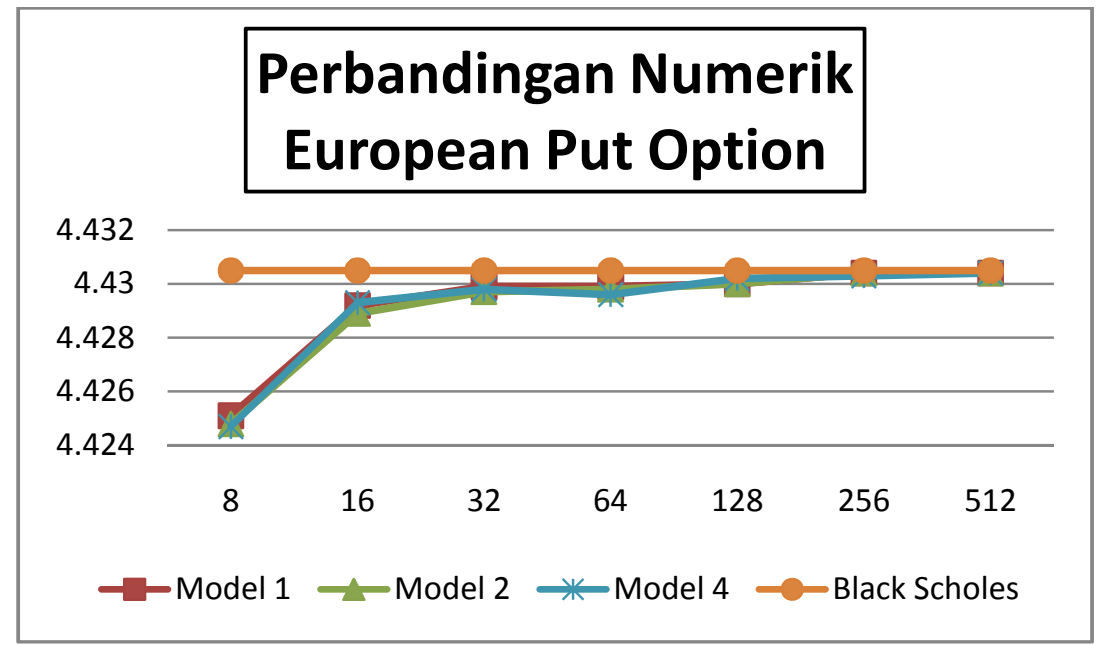

GAMBAR 5. Perbandingan Numerik European Put Option Model 1, 2, dan 4 


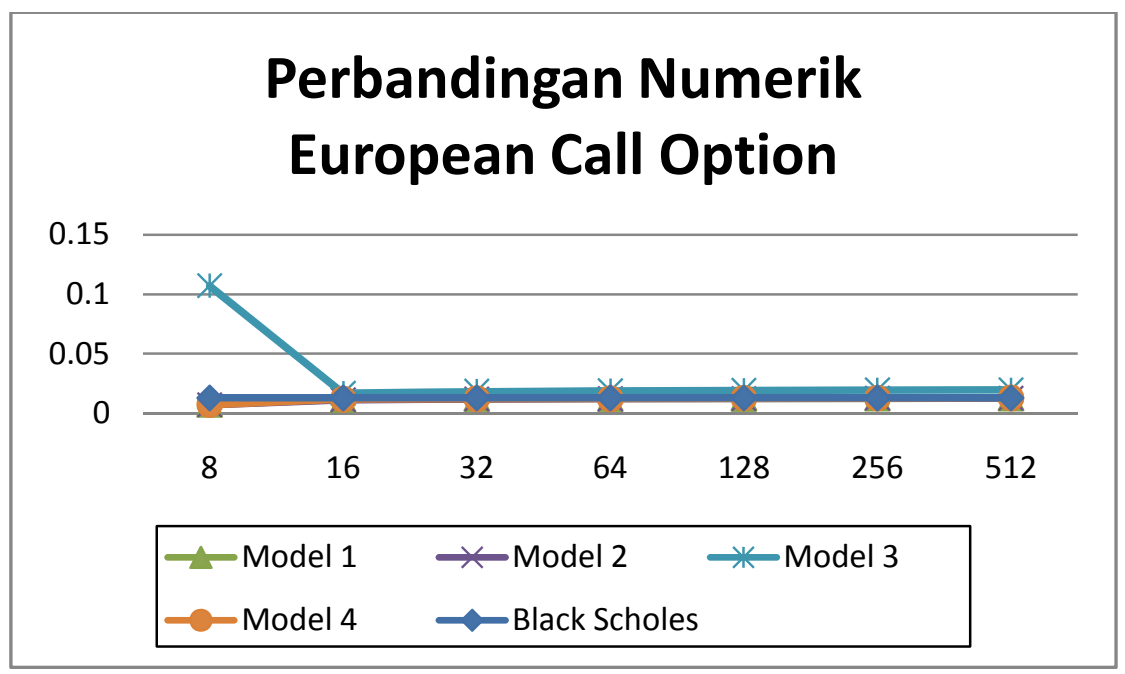

GAMBAR 6. Perbandingan Numerik European Call Option Model 1, 2,3 dan 4

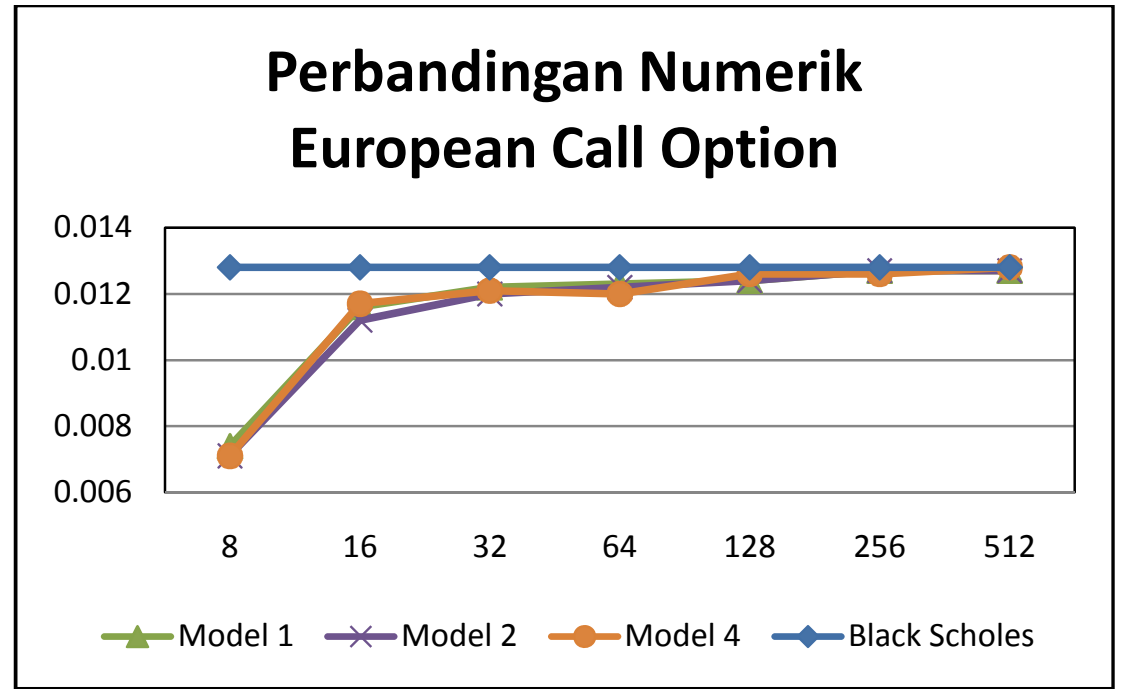

GAMBAR 7. Perbandingan Numerik European Call Option Model 1, 2, dan 4

Dari tabel dan garfik perbandingan di atas dapat dilihat bahwa aproksimasi binomial model 3 sangat tidak sesuai atau paling lemah dan besar galatnya dibandingkan dengan ketiga model lainnya karena dihasilkan dengan melibatkan banyak aproksimasi dalam menghasilkan perumusannnya. Untuk kasus European Put Option, model 3 under estimate, sedangkan untuk kasus European Call Option, model 3 over estimate.

\section{Kesimpulan}

Model Binomial, kecuali model 3, dapat digunakan sebagai pendekatan diskritisasi dalam menentukan nilai option. Semakin besar banyaknya grid, M, maka metode ini akan semakin mendekati pada nilai option dengan model Black-Scholes.

Aproksimasi binomial model 3 sangat tidak sesuai atau paling lemah dan besar galatnya dibandingkan dengan ketiga model lainnya karena dihasilkan dengan melibatkan banyak aproksimasi dalam menghasilkan perumusannnya. Untuk kasus European Put Option, model 3 under estimate, sedangkan untuk kasus European Call Option, model 3 over estimate. 


\section{Daftar Pustaka}

Figlewski, Stephen, (1990), Theoretical Valuation Models, dalam: Financial Options

From Theory To Practice, Salomon Brothers Center for the Study of Financial Institutions, New York University.

Hull, John C., (2003), Options, Futures, and Other Derivatives, fifth edition, Prentice Hall, New Jersey.

Ross, Sheldon M., (1999), An Introduction to Mathematical Finance, Option and Other Topics, Cambridge University Press.

Stampfli, J., Goodman, V., (2001), The Mathematics of Finance, Brooks/Cole, USA. 